\title{
Fire Risk Assessment and Computer Simulation of Fire Scenario in Underground Mines
}

\author{
Vancho Adjiski ${ }^{1}$, Zoran Despodov ${ }^{1}$, Dejan Mirakovski ${ }^{1}$, Stojance Mijalkovski ${ }^{1}$ \\ ${ }^{1}$ Faculty of Natural and Technical Sciences, Mining engineering, "Goce Delchev” University, P.O. Box 201, 2000-Shtip, \\ R.Macedonia \\ Correspondence: Vancho Adjiski, Faculty of Natural and Technical Sciences, Mining engineering, "Goce Delchev" \\ University, P.O. Box 201, 2000-Shtip, R.Macedonia
}

Received: May 19, 2015 Accepted: June 8, 2015 Online Published: June 24, 2015

doi:10.11114/set.v2i1.825 URL: http://dx.doi.org/10.11114/set.v2i1.825

\begin{abstract}
Unsafe working conditions in underground mines have led to a number of accidents, loss of life, damage to property, interruption of production, etc. Safety is essential in mining industry, which in recent years mainly focuses on injury prevention in the workplace through a variety of procedures and employee training. The primary goal of this paper is to present a methodology with systematic analysis to determine the most risky places for fire occurrence in underground mines and using a computer simulation to determine the movement of smoke and fire gases trough underground mining facilities from which depends the safe evacuation of all employees.
\end{abstract}

Keywords: underground mines, fire risk assessment, modeling fire scenarios, computer simulation

\section{Introduction}

Fires that occurred in underground mines, generate many dangers and problems for the people that are affected by this emergency situation. Because of this it is required more detailed research in this area and proposing appropriate measures to reduce the risk caused by fires. In underground mines, fire can occur anywhere where flammable material is located, but it is practically impossible to predict all possible locations for fire scenarios (Conti et al., 2005). Using a systematic analysis, this list of fire locations can be limited to those places that have the highest risk of fire occurrence (Iannacchione et al., 2008). Results from the fire assessment can be used to identify and locate the most destructive fire scenarios in underground mines, and with help of computer simulation to build effective system for evacuation.

Traditionally the most analysis for evacuation of fire scenarions accidents, focus more on commercial buildings and the evacuation of large populations in public areas. Evacuation systems of this type are many and also well documented. However systems for evacuation in case of fire in underground mines are little and relatively limited.

There are attempts from previous researches of making an effective system for evacuation in case of fire in underground mines, but they all have certain limitations in terms of accuracy, because they are based on simplified 2D maps that do not include the actual sizes of the mine together with many ramps, shafts, tunels, etc.

Therefore in this research paper will attempt to develop methodology that include fire risk assessment and computer simulation of fire scenario which will show the safe routes for evacuation and rescue in case of fire in underground mines. This presented model will have increased accuracy compared to other models presented so far, because of the prepared 3D model of the underground mine which involved actual dimensions of mine along with its associated elements from which the fire dynamics and system for evacuation depends.

\section{Evaluation of Risk Assessment for Occurrence of Possible Fire Scenarios in Underground Mine "Sasa" - R.Macedonia}

The first step in this analysis is the identification of potential fire locations, fire types and the associated consequences. In order to do this a fire risk assessment is necessary. Underground mine fire sources include, but not limited to (Mitchell, 1996):

- Mobile diesel equipment;

- Conveyor belts; 
- Compressor stations;

- Electrical substations;

- Oil/Lubricant, diesel storage warehouses;

- Grinding/welding areas in shops and in mine/plant;

- Shop maintenance areas;

- Powder/explosive magazines;

- Tires and wood in warehouses.

Each of these areas need to be examined by experts and engineering personnel and the seriousness of each fire scenario are determined by the potential frequency of the hazard, number of people affected, potential spread of contaminants, cost of damage etc. The more formal, team-based risk assessment for identification of potential fire location scenarios, include the following:

- Reviewing an entire work area;

- Reviewing manuals for working processes;

- Observing introduction to new working process;

- Implementing of new equipment;

- Observing sources of danger associated to the process' tasks/activities;

- Reviewing statistical data of past injuries.

Statistically, the biggest cause for initiating fires in underground mines is the diesel mechanization and warehouses for storage of diesel fuel and other flammable materials (Mallett \& Brnich, 1999). For identification of possible fire scenarios in underground mine for lead and zinc "Sasa" - R.Macedonia, we will be reviewing and observing sources of danger in all work areas and we will use the manuals for working processes and the diesel mechanization to identify all potential fire scenarios. From the manuals of working processes and the diesel mechanization of "Sasa" mine we identified possible fire scenarios from working diesel mechanization: Minetruck MT 2010, Scooptram ST3.5 and from working activities in the warehouse for diesel fuel.

The locations of possible fire scenarios, caused by the above mentioned diesel mechanization will mostly depend on the frequency of their work activities through all underground mining facilities (Zalosh, 2003). To eliminate less risky places for occurrence of fire scenarios from this diesel mechanization we will discard those places in the underground mine where this mechanization has a minimum operating activities (Jain, 2007).

The first step in the analysis of occurrence for possible fire scenario is the identification of potential fire sites, analysis of combustible materials and the associated consequences of the fire (Bahr, 1997). In order to make this calculation, you need risk analysis that would single out the most risky locations of occurrence of fire scenarios (Thyer, 2002) .

The method that will be used in this risk assessment is the modified matrix method that can be used to assess the risks in the workplace, the ranking of the different risks, the acceptability of risk and priority ranking (Donoghue, 2000). The advantage of this method is that can be easily understood by all employees in the mine.

Fire risk assessment is possible if we know the nature of dangers, harms and the factors that define the intensity. The data obtained by fire risk assessment is combined with data from other sources (such as data obtained by monitoring employees' health, permissible levels of exposure and available statistical data, exposure limit values, etc). In this matrix method for fire risk assessment, the risk is seen as the emergence of dangers and hazards. This fire risk assessment is the product of two dimensions (Donoghue, 2000):

- The severity of consequences for an employee in case of fire occurrence;

- The probability and frequency of fire occurrence.

The term consequence in the risk assessment can be considered as the "worst case scenario" or outcome that can be reasonably expected if fire incident occur. Generally, consequences can occur in two areas: personal injury/death and property/process damage. The probability of an incident occurring is largely dependent on the exposure frequency. The following aspects should be considered defining the probability:

- The number of times that fire situations occur;

- The number of people that are exposed;

- What has happened in the past in similar situations.

Once the consequence and probability of each potential fire scenario has been determined, the corresponding numerical value for consequence and probability from the respective tables can be used to determine the "level of risk". The values for consequence and probability are divided in 4 categories of risk, namely: high, medium, low and insignificant. The numerical value is assigned to each category of risk in that manner that the highest risk has the biggest number.

The riskiest locations in "Sasa" mine for fire scenarios caused by loader Scooptram ST 3.5, are those locations where 
this mechanization is mostly used, and these locations are the excavation bloks. Next step is to determine the size of the associated risks and to determine whether these risks are tolerable (Raman, 2003).

Table 1. Consequence Evaluation

\begin{tabular}{lll}
\hline & CRITERIA OF INJURIES AND DAMAGE CAUSED BY FIRE & VALUE \\
\hline & - Death of one or more people & HIGH \\
& - Permanent disability & $(8)$ \\
& - Irreparable damage to materials & \\
& - Loss in production & - Factors affecting the Company's image \\
Consequence & - Injuries causing temporary disability of one or more persons & MEDIUM \\
(C) & - Remediable or partial damage of the working machinery & $(4)$ \\
& - Non-disabling injuries & LOW \\
& - Damage to materials that do not affect the production process & $(2)$ \\
& - Minimum production losses & INSIGNIFICANT \\
\end{tabular}

Table 2. Probability Evaluation

$\begin{array}{ll}\text { CRITERIA TO ESTIMATE PROBABILITY } & \text { VALUE } \\ \text { Probability that fire incident may occur over eight (8) times in a year } & \text { HIGH }\end{array}$

(8)

Probability

(P)

Probability that fire incident may occur from two (2) to eight (8) times a year

(4)

Probability that fire incident may occur once (1) a year

Probability that a fire scenario does not become an incident during the year

Table 3. Risk Magnitude Calculation

\begin{tabular}{llllll}
\hline & Consequence (C) & & & \\
& & 1 & 2 & 4 & 8 \\
Probability & 1 & 1 & 2 & 4 & 16 \\
$(\mathrm{P})$ & 2 & 2 & 4 & 16 & 32 \\
& 4 & 4 & 8 & 32 & 64 \\
\hline
\end{tabular}

Risk Magnitude (MR) of accident from fire scenario is obtained by multiplying Probability (P) times Consequence (C) (Pattnaik, 2009).

Table 4. Analysis of possible locations for the occurrence of fire scenario from loader Scooptram ST3.5

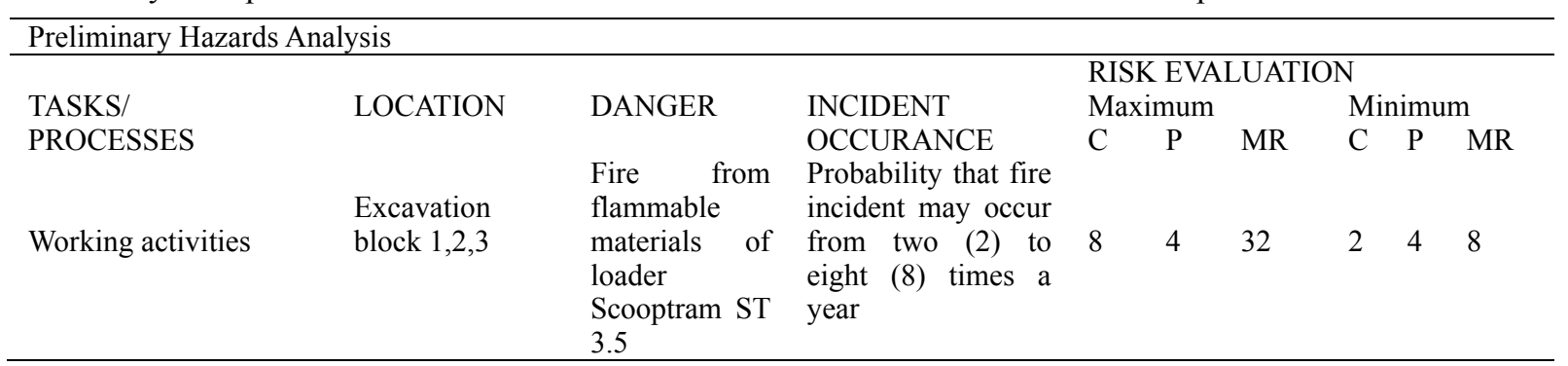

The riskiest locations in "Sasa" mine for occurrence of fire scenarios caused by diesel machinery Minetruck MT 2010, are those locations where this mechanization is mostly used and these are the mining transport ramps. 
Table 5. Analysis of possible locations for the occurrence of fire scenario from diesel machinery Minetruck MT 2010

Preliminary Hazards Analysis

TASKS/

PROCESSES

LOCATION

DANGER

INCIDENT

OCCURANCE

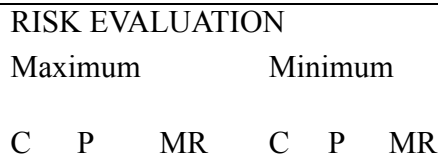

Fire from

flammable Probability that fire

Working activities

Mining transport ramps incident may occur

once (1) a year

8

2

16

224 materials of

diesel

machinery

Minetruck

MT 2010

From the manuals for working processes in "Sasa" mine is identified possible fire scenario from working activities in the warehouse for diesel fuel

Table 6. Analysis of the location of fire scenario occurrence in the warehouse for diesel fuel

\begin{tabular}{|c|c|c|c|c|c|c|c|c|c|}
\hline \multicolumn{10}{|c|}{ Preliminary Hazards Analysis } \\
\hline \multirow{3}{*}{$\begin{array}{l}\text { TASKS/ } \\
\text { PROCESSES }\end{array}$} & \multirow{3}{*}{ LOCATION } & \multirow{3}{*}{ DANGER } & \multirow{3}{*}{$\begin{array}{l}\text { INCIDENT } \\
\text { OCCURANCE }\end{array}$} & \multicolumn{6}{|c|}{ RISK EVALUATION } \\
\hline & & & & \multicolumn{3}{|c|}{ Maximum } & \multicolumn{3}{|c|}{ Minimum } \\
\hline & & & & $\mathrm{C}$ & $\mathrm{P}$ & MR & $\mathrm{C}$ & $\mathrm{P}$ & MR \\
\hline Working activities & $\begin{array}{l}\text { Warehouse for } \\
\text { diesel fuel }\end{array}$ & $\begin{array}{l}\text { Fire from } \\
\text { diesel fuel }\end{array}$ & $\begin{array}{l}\text { Probability that fire } \\
\text { incident may occur } \\
\text { over eight ( } 8) \text { times } \\
\text { in a year }\end{array}$ & 8 & 8 & 64 & 2 & 8 & 16 \\
\hline
\end{tabular}

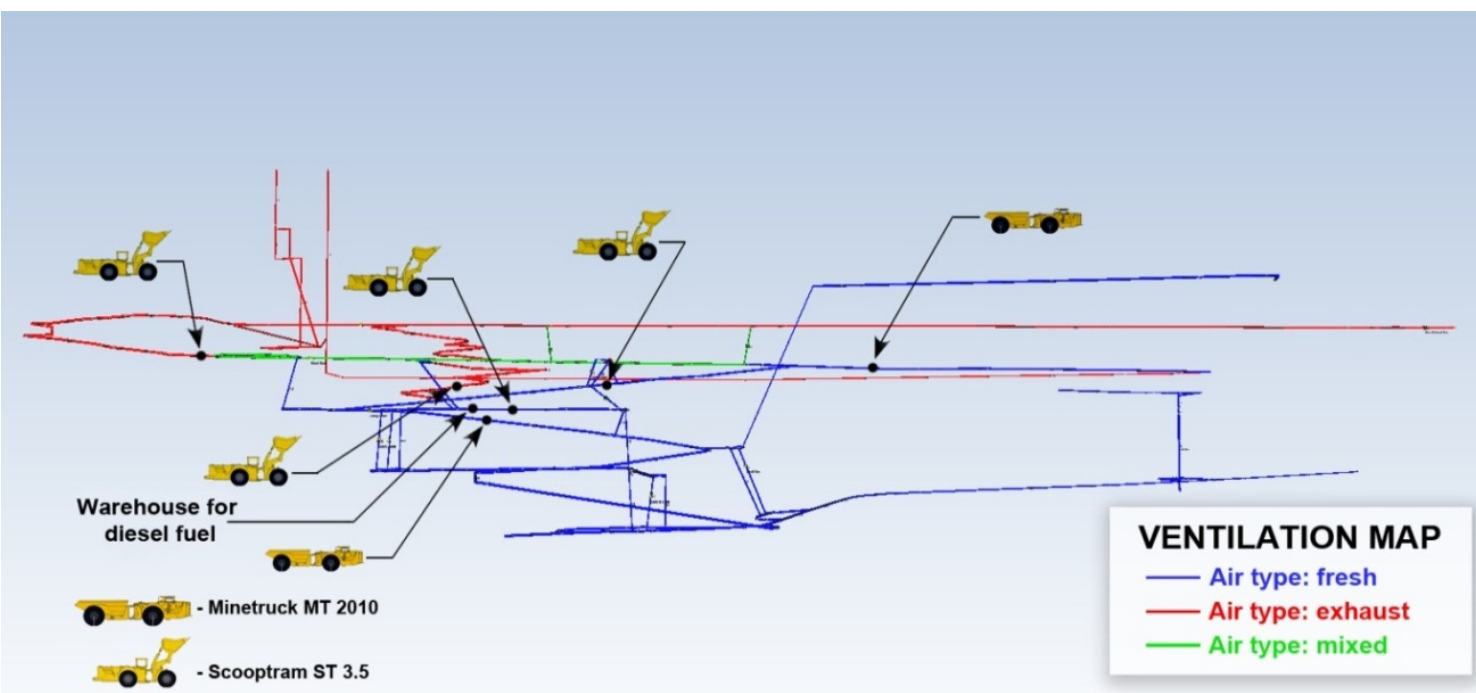

Figure 1. Possible fire scenarios in underground mine for lead and zinc ore - "Sasa" R.Macedonia

From the results obtained from fire risk assessment done in "Sasa" mine we identified the fire scenario in the warehouse for diesel fuel to be most destructive. For this fire scenario we will make fire model and with help of computer simulation we will determine the movement of smoke and fire gases and based on these results we will identify the safe routes for evacuation and rescue (Kumar, 2014).

\subsection{Modeling of Fire Scenario in the Warehouse for Diesel Fuel in Underground Mine "Sasa" - R.Macedonia}

In this analysis for modeling of fire scenario in the warehouse for diesel fuel in underground mine "Sasa" R.Macedonia, we will not analyze possible sources of ignition of the fire but will assume that the fire has already happened and thus we analyze only the products of combustion from the fire scenario and their movement through underground mining facilities. Fire model describes the fire characteristics, such as for example: heat release rate, heat flow, burning rate of material, generating toxic gases, smoke, etc (Hansen, 2010). 
Table 7. Properties of diesel fuel

\begin{tabular}{ll}
\hline Diesel fuel & \\
\hline Diesel fuel in the tank & $1000 \mathrm{l}$ \\
Density of diesel fuel & $918 \mathrm{~kg} / \mathrm{m}^{3}$ \\
Simplified chemical hydrocarbon formula of diesel fuel & $\mathrm{C}_{12} \mathrm{H}_{23}$ \\
Heat of combustion & $46108 \mathrm{~kJ} / \mathrm{kg}$ \\
Burning rate of Diesel fuel (experimental data) (Totten et al., & $0.045 \mathrm{Kg} / \mathrm{m}^{2} *_{S}$ \\
2003 ) & \\
\hline
\end{tabular}

From the software for modelling fires Pyrosim (PyroSim User Manual, 2012), and the chemical and physical characteristics of the diesel fuel (Table.7), we get the following experimental software results for burning 1000 litres of diesel fuel:

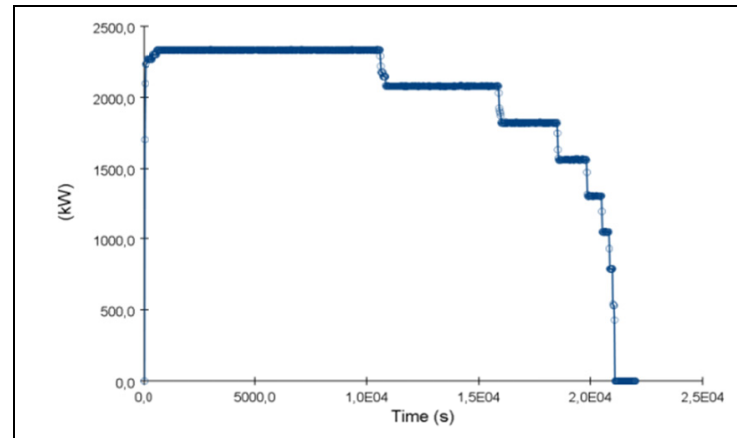

Figure 2. Heat release rate

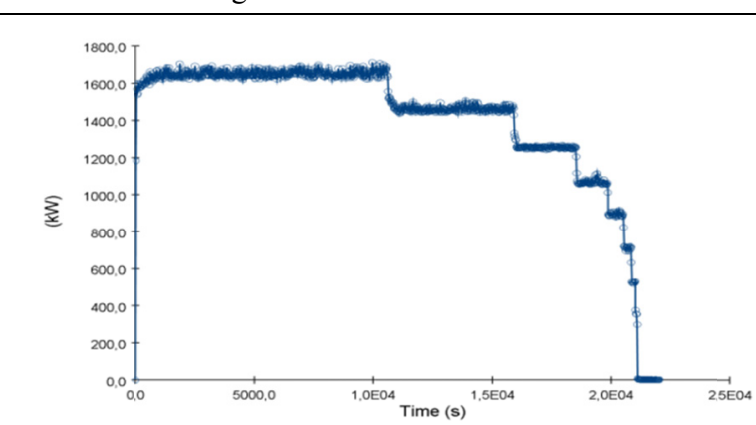

Figure 4. Heat flow

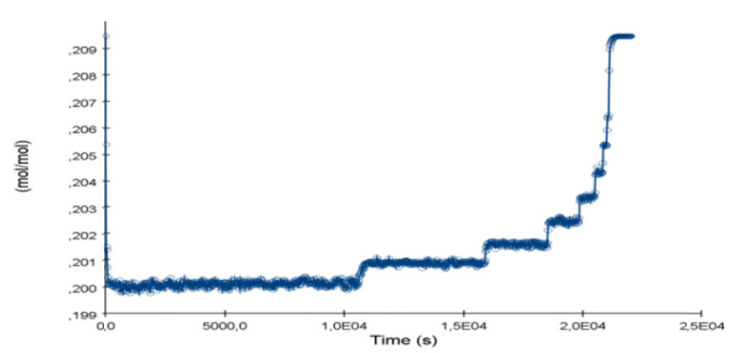

Figure 6. Oxygen in fire place

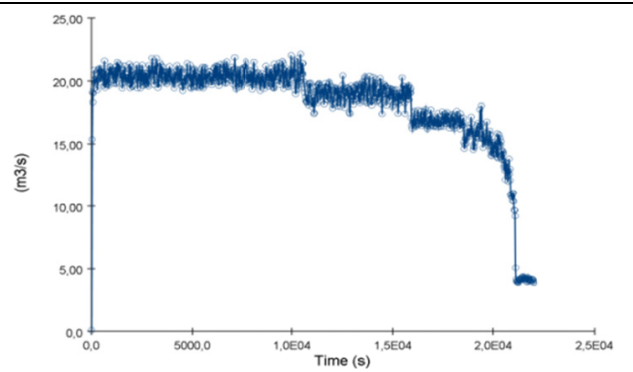

Figure 3. Volume flow of smoke and fire gases generated by the fire

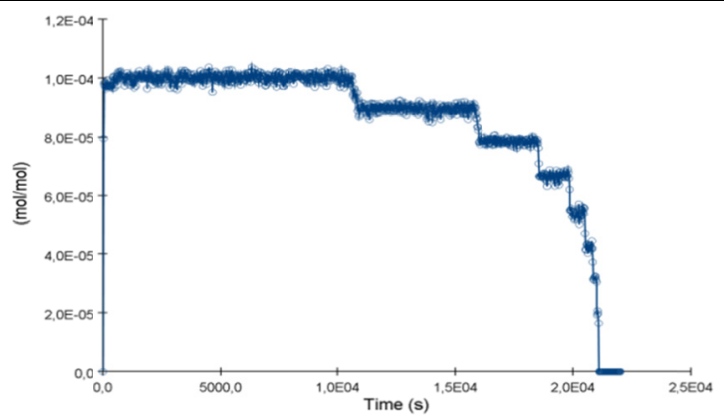

Figure 5. Generation of carbon monoxide from fire

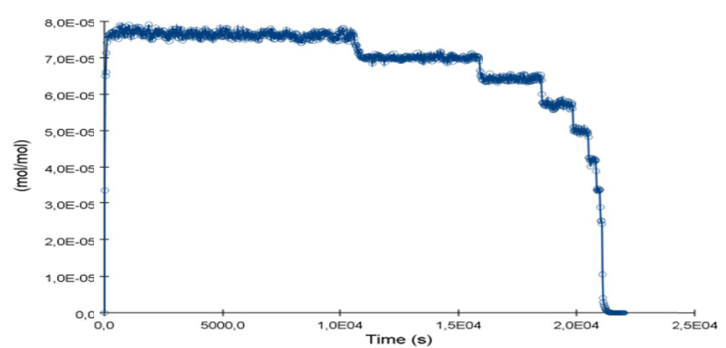

Figure 7. Generating soot from fire

\section{Scenario 1:}

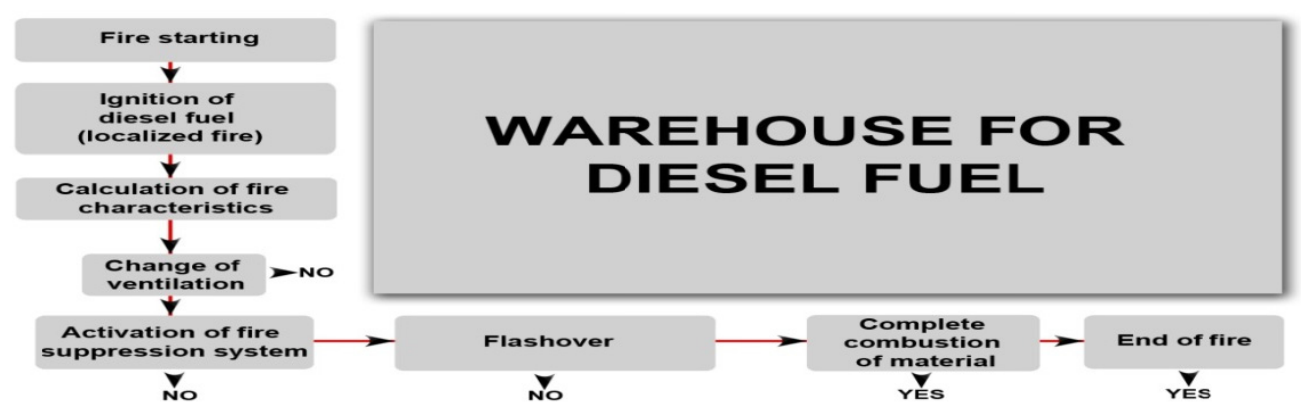

Figure 8. Process of modelling fire scenario 1 
To calculate the movement of smoke and fire gases in the previously specified location in the underground mine "SASA" - R.Macedonia, we will use the software MINEFIRE PRO + (MineFire Pro+ User Manual, 2013). In the software MINEFIRE PRO+ we are entering the previously calculated fire characteristics from the software Pyrosim, for the fire pool caused by leakage and ignition of 1000 litres of diesel fuel from the warehouse for diesel fuel.

Table 8. Input fire parameters in software MINEFIRE PRO +, for fire scenario 1

\begin{tabular}{|c|c|c|c|c|c|}
\hline $\begin{array}{l}\text { Volume flow of } \\
\text { smoke and fire } \\
\text { gases generated } \\
\text { by the fire, } \\
\left(\mathrm{m}^{3} / \mathrm{s}\right)\end{array}$ & $\begin{array}{l}\text { Concentration of } \\
\text { carbon monoxide in } \\
\text { the volume flow of } \\
\text { smoke and fire } \\
\text { gases } \mathrm{CO},(\%)\end{array}$ & $\begin{array}{l}\text { Heat Flow } \\
\text { from the fire, } \\
(\mathrm{kW})\end{array}$ & $\begin{array}{l}\text { Concentration } \\
\text { oxygen in the fire } \\
\text { location } \mathrm{O}_{2},(\%)\end{array}$ & $\begin{array}{l}\text { Volume flow } \\
\text { of air in the } \\
\text { branch } \\
\left(\mathrm{m}^{3} / \mathrm{s}\right)\end{array}$ & $\begin{array}{l}\text { Time for } \\
\text { complete } \\
\text { development of } \\
\text { the fire (min) }\end{array}$ \\
\hline 14.42 & 0.0077 & 1053.3 & 20 & 13 & 1 \\
\hline
\end{tabular}

In software Pyrosim for fire scenario 1, for complete combustion of 1000 litres of diesel fuel, we obtained the fire time length of 366.6 minutes. From the analysis and calculations of fire scenario 1, done in software MINEFIRE PRO +, we get the following results for movement and spread of smoke and fire gases:

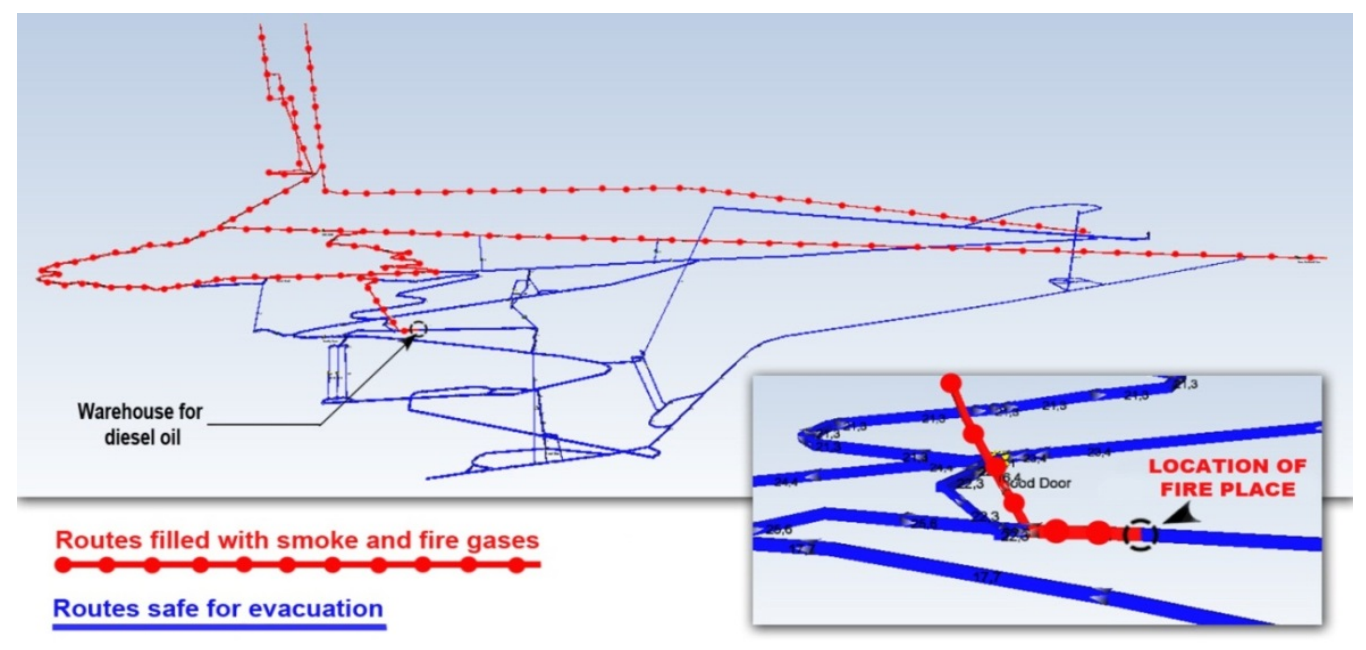

Figure 9. Calculations for movement of smoke and fire gases made in software MINEFIRE PRO + for fire scenario 1

The next step after the analysis and calculations for the movement of smoke and fire gases generated by the fire scenario 1, is locating the position of all workers in the underground mine and giving them orders and guidelines based on the previously calculated safe routes for evacuation (Figure 9).

\section{Conclusion:}

Risks of fire occurrence in underground mines are known for a long time. Accidents caused by fire not only can cause damage or at worst deadly consequences, but also cause big expenses because of losses in production, repairs and loss of good will to work.

The quick action and preconditioning for dealing this kind of emergency can help save lives and protect the financial investments in the mine.

The purpose of this fire risk assessment in underground mines is the identification of possible fire scenarios and their harmful consequences for the life of employees and also finding preventive measures to reduce this risks.

This paper presents a methodology for analyzing the risk of fire occurrence, and a system for modeling and simulation of fire scenario which can produce effective system for evacuation in case of fire in underground mines.

\section{References}

Bahr, J. (1997). System Safety Engineering And Risk Assessment: A Practical Approach, Taylor And Francis, NY

Conti, R., Chasko, L., \& Wiehagen, W. (2005). Fire Response Preparedness For Underground Mines. National Institute For Occupational Safety And Health-NIOSH, Pittsburgh Research Laboratory, Pittsburgh, PA,

Hansen, R. (2010). Design Fires In Underground Mines (Doctoral Dissertation). Mälardalen University, Sweden

Iannacchione, A., Varley, F., \& Brady, T. (2008). The Application Of Major Hazard Risk Assessment (MHRA) To Eliminate Multiple Fatality Occurrences In The US Minerals Industry. U.S Department Of Health And Human Services. Centers For Disease Control And Prevention. National Institute For Occupational Safety And Health Spokane Research Laboratory Spokane, WA, 
Jain, S. (2007). Environmental And Safety Risk Assessment In Mines (Master's Thesis). Department Of Mining Engineering. National Institute Of Technology Rourkela, Orissa,

Kumar, P. (2014). Risk Analysis By Using Failure Mode And Effects Analysis For Safe Mining. International Journal Of Science And Research, (IJSR), 3(11), 2512-2515

Mallett, L., \& Brnich, M. (1999). Focus On Prevention: Conducting A Fire Risk Assessment. U.S. Department Of Health And Human Services. Centers For Disease Control And Prevention. National Institute For Occupational Safety And Health, Pittsburgh Research Laboratory, Pittsburgh, PA,

Minefire Pro+ User Manual, A Simulator For Underground Fires. (2013). (USER'S MANUAL \& TUTORIAL), Mine Ventilation Services, Inc., Clovis, CA, USA

Pattnaik, S. (2009). Assessment Of Safety And Environmental Risk In Mines (Master's Thesis). Department Of Mining Engineering. National Institute Of Technology Rourkela, Orissa

Pyrosim User Manual-Pyrosim Documentation. (2012). (User Manual Of Computer Code), Thunderhead Engineering Consultants, Inc.Manhattan, KS, USA

Raman, R. (2003). Underground Mine Safety- Are We Doing Enough?, Kellogg Brown \& Root Pty Ltd, Sydney

Thyer. A. (2002). Development Of A Fire And Explosion Risk Assessment Methodology For Underground Mines. Health And Safety Laboratory, United Kingdom,

Totten, G., Westbrook, S., \& Shah, R. (2003). Fuels And Lubricants Handbook: Technology, Properties, Performance, And Testing, Vol.1, ASTM International, West Conshohocken, PA

Zalosh, R. (2003). Industrial Fire Protection Engineering. John Wiley \& Sons Ltd, Worcester, WA. http://Dx.Doi.Org/10.1002/9781118903117

This work is licensed under a Creative Commons Attribution 3.0 License. 